\title{
ANALISA FAKTOR KETERLAMBATAN PEKERJAAN PROYEK (Studi Kasus : Pembangunan Rawat Inap Puskesmas Sungai Guntung Kec. Kateman Kab. Inhil Tahun Anggaran 2017)
}

\author{
Kusmaran \\ Prodi Teknik Sipil, Fakultas Teknik dan Ilmu Komputer, Universitas Islam Indragiri, Tembilahan \\ Email: irandmancoy@gmail.com (korespondensi)
}

\begin{abstract}
Construction Projects is one form of activity that takes place in a limited period of time, with certain resources, to achieve results in the form of buildings or infrastructure. Construction projects involve contractors, project owners, planning consultants and supervisory consultants that are interrelated in a work agreement called a contract. Project delays for contractors will experience a loss of time and costs, because the benefits expected by the contractor will decrease or even not get the expected benefits that they may not even benefit at all. The delay in the completion of the project work will cause a loss to the Owner to the operating time of the project results, so that the use of the project development results will be delayed or late. The success of a construction project is determined by the suitability of time, cost and quality stipulated in the contract document. In the implementation of construction projects delays often occur due to the parties involved. This research was conducted with the aim of finding out the factors causing delays in the implementation of construction projects according to contractors, project owners and supervisory consultants. Conducted by distributing questionnaires to contractors, supervisors and consultants, the results obtained were processed using the SPSS program. The results of the study revealed that the factors that caused the delay in construction projects were the 3 most dominant were the lack of skilled labor in the category of human resources Unexpected weather falls into the category of external aspects, and differences in interpretation of work codes fall into the categories of organization, coordination and communication aspects.
\end{abstract}

Keywords: Delays, Construction Projects, Buildings, SPSS,

\begin{abstract}
Abstrak
Proyek Konstruksi merupakan salah satu bentuk kegiatan yang berlangsung dalam jangka waktu terbatas, dengan sumber daya tertentu, untuk mencapai hasil dalam bentuk bangunan atau infrastruktur. Proyek konstruksi melibatkan kontraktor, pemilik proyek, konsultan perencana dan konsultan pengawas yang saling terkait dalam sebuah perjanjian kerja yang disebut kontrak. Keterlambatan proyek bagi kontraktorakan mengalami kerugian waktu dan biaya, karena keuntungan yang diharapkan oleh kontraktor akan berkurang atau bahkan tidak mendapatkan keuntungan yang diharapkan bahkan bisa tidak mendapat keuntungan sama sekali. Keterlambatan penyelesaian pekerjaan proyek akan menyebabkan kerugian bagi Owner terhadap waktu operasi hasil proyek, sehingga penggunaan hasi pembangunan proyek menjadi mundur atau terlambat. Keberhasilan suatu proyek konstruksi ditentukan dari kesesuaian waktu, biaya dan mutu yang ditetapkan dalam dokumen kontrak. Dalam pelaksanaan proyek konstruksi sering terjadi keterlambatan yang disebabkan oleh pihakpihak yang terlibat. Penelitian ini dilakukan dengan tujuan untuk mengetahui factor penyebab keterlambatan pelaksanaan proyek konstruksi menurut kontraktor, pemilik proyek dan konsultas pengawas. Dilakukan dengan menyebarkan kuisioner kepada kontraktor, pemilik dan konsultan pengawas, hasil yang diperoleh diolah menggunakan program SPSS, Hasil penelitian tersebut diketahui bahwa factor penyebab keterlambatan pelaksanaan proyek konstrusi terdapat 3 yang paling dominan adalah Kurangnya tenaga kerja terampil masuk dalam kategori aspek sumber daya manusia, keadaan cuaca yang tak terduga masuk dalam kategori aspek eksternal, dan perbedaan intepretasi kode pekerjaan masuk dalam kategori aspek organisasi, koordinasi dan komunikasi.
\end{abstract}

Kata kunci: Keterlambatan, Proyek Konstruksi, Gedung, SPSS. 


\section{PENDAhUlUan}

\subsection{Latar Belakang}

Proyek konstruksi sering mengalami kinerja yang buruk dalam hal keterlambatan waktu, pembengkakan biaya dan rendahnya kualitas. Ketiga hal tersebut merupakan satu kesatuan yang saling berkaitan. Keterlambatan terjadi pada proyek akan ada tambahan biaya yang harus dikeluarkan di luar kontrak dan dapat menyebabkan kerugian bagi pihak-pihak yang terkait khususnya pelaksana konstruksi, diperlukan perhatian lebih terhadap keterlambatan dan rendahnya kualitas.(Indra Pandu Prastyo, 2012)

Proyek konstruksi di Kabupaten Indragiri Hilir ini tidak sedikit yang mengalami terlambatnya pelaksanaan pekerjaan proyek. Segala hal dari permasalahan yang ada dilapangan maupun proses pengurusan administrasi, Sehingga dapat memperpanjang waktu yang dibutuhkan untuk menyelesaikan suatu pekerjaan berdasarkan kontrak. Penambahan biaya bisa terjadi dan keterlambatan juga berpengaruh pada adanya Time Overrun, perselisihan, arbritasi, pemutusan hubungan kerja dan ligitasi.

Keterlambatan proyek bagi kontraktor akan mengalami kerugian waktu dan biaya, karena keuntungan yang diharapkan oleh kontraktor akan berkurang atau bahkan tidak mendapatkan keuntungan yang diharapkan bahkan bisa tidak mendapat keuntungan sama sekali. Keterlambatan penyelesaian pekerjaan proyek akan menyebabkan kerugian bagi Owner terhadap waktu operasi hasil proyek, sehingga penggunaan hasi pembangunan proyek menjadi mundur atau terlambat.

Keterlamatan dalam pelaksanaan proyek ini penulis akan meneliti faktor-faktor yang sangat mempengaruhi penyebab mengapa banyak proyek konstruksi yang tidak selesai pada waktu yang telah ditetapkan pada kontrak perjajian kerja. Disini penulis akan mengkaji tentang keterlambatan pekerjaan proyek yang kami ambil studi kasusnya Pembangunan Rawat Inap Puskesmas Sungai Guntung Kecamatan Kateman Kab. Inhil yang merupakan daerah pesisir jauh dari kabupaten kota.

\subsection{Perumusan masalah}

Inti dari suatu penelitian terletak pada perumusan masalahnya. Berdasarkan latar belakang yang telah diuraikan sebelumnya, maka akan dihasilkan suatu rumusan masalah yang akan dijawab pada penelitian ini, berikut rumusan masalah yang harus dijawab dalam penelitian ini:
1. Faktor-faktor yang menyebabkan keterlambatan pekerjaan pada proyek konstruksi di Kabupaten Indragiri Hilir

2. Penyebab terjadinya keterlambatan pada proyek konstruksi.

3. Penambahan waktu pelaksanaan pekerjaan pada proyek konstruksi

4. Lintasan kritis pada pelaksaan proyek konstruksi

5. Keterlambatan proyek Pembangunan Rawat Inap Puskesmas Guntung Kecamatan Kateman.

6. Pendapat atau wawancara terhadap responden mengguanakan kuisioner.

7. Langkah mitigasi apa yang harus diambil terhadap faktor utama penyebab keterlambatan pekerjaan?

\subsection{Batasan Penelitian}

Mengingat waktu penelitian yang terbatas dan dengan tujuan agar penelitian ini terarah pada sasaran yang telah ditetapkan, maka terdapat beberapa batasan dalam pokok bahasan, antara lain:

1. Peninjauan dari sudut pandang dari responden terhadap keterlambatan proyek konstruksi kepada :

a. Owner / pemilik proyek

b. Konsutan pengawas

c. Kontraktor pelaksana

d. Masyarakat dilokasi proyek/umum

2. Penelitian pada studi kasus proyek Pembangunan Rawat Inap Puskesmas Guntung Kecamatan Kateman.

3. Berdasarkan wawancara dan kuesioner terhadap kontraktor terkait.

\subsection{Tujuan Penelitian}

Berdasarkan rumusan masalah yang telah dijabarkan sebelumnya, maka dapat diketahui tujuan dari penulisan penelitian ini adalah untuk mengidentifikasi faktor-faktor utama yang berpengaruh terhadap keterlambatan pekerjaan proyek konstruksi, khususnya proyek Pembangunan Rawat Inap Puskesmas Sungai Guntung Kecamatan Kateman Kab. Inhil yang merupakan studi kasus penelitian kami.

\subsection{Manfaat Penelitian}

Berikut ini adalah beberapa manfaat yang diharapkan dapat diberikan dari penulisan tugas akhir ini:

1. Bagi kontraktor, dapat dijadikan sebagai salah satu bahan referensi untuk menghindari terjadinya keterlambatan pekerjaan konstruksi.

2. Bagi lingkungan akademis khusunya mahasiswa, dapat menjadi bahan acuan untuk mahasiswa yang tertarik dengan penyebab keterlambatan pekerjaan pada 
proyek konstruksi

\section{STUDI PUSTAKA}

\subsection{Pengertian manajemen}

Pengertian Manajemen, menurut Sidharta Kamarwan, dapat dilihat dari beberapa sudut pandang (referensi), di antaranya sebagai berikut.

1. Manajemen sebagai suatu ilmu pengetahuan (management as a science), adalah bersifat interdisipliner yang dalam hal ini mernperguhakan bantuan dari ilmu-ilmu sosial, filsafat, clan matematika.

2. Manajemen sebagai suatu sistem (management as a system) adalah suatu rangkaian kegiatan yang masingmasing kegiatan dapat dilaksanakan tanpa menunggu selesainya kegiatan lain, walaupun kegiatan-kegiatan tersebut saling terkait untuk mencapai tujuan organisasi.

3. Manajemen sebagai suatu proses (management as a process) adalah serangkaian tahap kegiatan yang diarahkan pada pencapaian suatu tujuan dengan pemanfaatan semaksimal mungkin sumber-sumber yang tersedia.

4. Manajemen sebagai kumpulan orang (management as people/ group of people) adalah suatu istilah yang dipakai dalam arti kolektif untuk menunjukkan jabatan kepemimpinan di dalam organisasi antara lain kelompok pimpinan atas, kelompok pimpinan tengah dan kelompok pimpinan bawah.

Kesimpulannya dari pendapat diatas adalah kemampuan untuk memperoleh hasil dalam rangka pencapaian tujuan melalui kegiatan sekelompok orang. Tujuan perlu ditetapkan terlebih dahulu sebelum melibatkan sekelompok orang yang mempunyai kemarnpuan atau keahlian dalam rangka pencapaian tujuan yang telah ditetapkan. Fungsi manajemen dengan kata lain juga untuk melaksanakan semua kegiatan yang diperlukan dalam pencapaian tujuan dengan batas-batas tertentu. dari beberapa surnber, terkumpul definisi-definisi dari beberapa ahli manajernen .(Irika windiasanti \& Lenggogeni, 2013).

\subsection{Pengertian dasar proyek konstruksi}

Istilah Constructie dalam Bahasa Belanda artinya sruktur (konstruksi), misalnya konstruksi kap baja, konstruksi kap kayu, konstruksi jembatan beton, konstruksi jembatan rangka baja, konstruksi jembatan kayu, konstruksi jalan raya, konstruksi bendungan, konstruksi lapangan terbang, dan Iain-lain, sedangkan Construction dalam bahasa Inggris artinya pembangunan. Jadi Construction Management System berarti sistem manajemen pembangunan.

Menurut Donald S. Barrie dan Boyd C. Paulson, Jr, terdapat 4 tipe utama konstruksi yaitu:

\section{Konstruksi Pemukiman (Residential Construction)}

Konstruksi ini meliputi rumah tunggal, rumah duplex, rumah susun, rumah susun (flat), apartemen, rumah pangsa yg diperlakukan milik sendiri (kondominium), kompleks perumahan dan pengembangan wilayah pemukiman, rumah dan toko (ruko) dan Iain-lain.

2. Konstruksi Gedung

(Building

Construction)

Konstruksi ini menghasilkan bangunanbangunan seperti gedung sekolah, fakultas, universitas, rumah sakit, gereja, mesjid, bangunan-bangunan bertingkat baik untuk perkantoran maupun untuk perdagangan (pasar, pusat pertokoan, mall), bioskop, gedung pemerintah, pusat rekreasi, pabrik industi kecil/ringan, pergudangan dan Iain-lain.

3. Konstruksi Rekayasa Berat (Heavy Engineering Construction)

Konstruksi ini meliputi pekerjaanpekerjaan bangunan bendungan, terowongan, jalan raya, penyaringan dan distribusi air minum, janngan irigasi, pemasangan pipa, pelabuhan/dermaga, bandar udara, jaringan listrik, jaringan komunikasi, reservoir, sistem penanganan dan pembuangan bahan limbah, bangunan lepas pantai (offshore), jalan kereta api (reil road) dan Iain-lain.

4. Konstruksi Industri (Industrial Construction)

Konstruksi ini meliputi proyek-proyek antara lain: proyek pembangunan pabrik besi beton, pabrik semen, pabrik peleburan logam, pabrik baja, pabrik aluminium, pabrik pupuk, pabrik gula, pabrik kain tenun, pabrik keramik, pabrik pesawat terbang, pabrik penggalangan kapal, fasilitas lainnya yang dibutuhkan oleh pelayanan umum, industri dasar dan Iain-lain.

\subsection{Keterlambatan Proyek (Project} Delay)

Keterlambatan proyek konstruksi berarti bertambahnya waktu pelaksanaan penyelesaian proyek yang telah direncanakan dan tercantum dalam dokumen kontrak. keterlambatan pelaksanaan proyek 
umumnya selalu menimbulkan akibat yang merugikan bagi pemilik maupun kontraktor karena dampak keterlambatan adalah konflik dan perdebatan tentang apa dan siapa yang menjadi penyebab, juga tuntutan waktu, dan biaya tambah.(Wirabakti, Abdullah, \& Maddeppungeng, 2014)

\subsubsection{Pengertian Keterlambatan}

Keterlambatan proyek konstruksi berarti bertambahnya waktu pelaksanaan penyelesaian yang telah direncanakan dan tercantum dalam dokumen kontrak. Penyelesaian pekerjaan tidak tepat waktu adalah merupakan kekurangan dari tingkat produktifitas dan sudah tentu kesemuanya ini akan mengakibatkan pemborosan dalam pembiayaan, baik berupa pembiayaan langsung yang dibelanjakan untuk proyek-proyek pemerintah, maupun berwujud pembengkakan investasi dan kerugian-kerugian pada proyek-proyek swasta. Peran aktif manajemen merupakan salah satu kunci utama keberhasilan pengelolahan proyek. Pengkajian jadwal proyek diperlukan untuk menentukan langkah perubahan mendasar agar keterlambatan penyelesaian proyek dapat dihindari atau dikurangi. Keterlambatan pada perumahan dan konstruksi ringan sering diakibatkan oleh miskomunikasi antara kontraktor, subkontraktor, dan pemilik. (Indra Pandu Prastyo, 2012)

\subsubsection{Jenis-jenis Keterlambatan}

Jenis

keterlambatan

dapat

diklasifikasikan menjadi 3 yakni :

1. Compensable Delays with Compensation dengan kompensasi adalah keterlambatan yang disebabkan oleh pemilik, antara lain kegagalan pemilik untuk menyerahkan tapak kepada kontraktor pada waktu yang telah disepakati, kesalahan desain atau ketidaklengkapan gambar dan spesifikasi, perubahan pekerjaan, kondisi tapak yang berbeda, kegagalan pemilik menyampaikan informasi vital ke kontraktor. Untuk jenis keterlambatan ini kontraktor diberikan kompensasi dalam bentuk tambahan waktu pelaksanaan dan penggantian biaya karena keterlambatan tersebut.

2. Compensable Delays without Compensation adalah keterlambatan yang tidak disebabkan oleh woner maupun kontraktor. Hal ini terjadi apabila kegiatan kontraktor terhambat karena kejadian yang tidak disebabkan baik oleh pemilik atau kontraktor. Keterlambatan ini tercantum dalam pasal dokumen kontrak sebagai "Force
Majeure". Kompensasi atas keterlambatan ini adalah perpanjangan waktu penyelesaian proyek saja, tidak ada penggantian biaya.

3. Non-Excusable Delays adalah keterlambatan di mana tindakan/perbuatan kontraktor yang menyebabkan keterlambatan. Keterlambatan ini terjadi karena kesalahan kontraktor, sub kontraktor, pemasok. Dalam kasus ini kontraktor tidak mendapatkan kompensasi apapun baik ganti rugi biaya maupun tambahan waktu, bahkan sebaliknya pemilik berhak untuk mengenakan denda atau meminta ganti rugi biaya kepada kontraktor akibat keterlambatan tersebut.(Indra Pandu Prastyo, 2012)

\subsection{Variabel}

Variabel adalah konstruk yang sifatsifatnya sudah diberi nilai dalam bentuk bilangan, sedangkan konstruk merupakan konsep yang dapat diamati dan diukur. Variabel dibagi atas tiga kategori yakni,

1. Variabel bebas dan Variabel tak bebas Variabel yang diduga sebagai penyebab atau pendahulu dari variabel yang lain disebut variabel bebas. Variabel yang diduga sebagai akibat atau yang dipengaruhi oleh variabel yang mendahuluinya disebut variabel tak bebas.

2. Variabel aktif dan Variabel atribut. Variabel yang dapat ditentukan atau dapat dikendalaikan seperti temperatur ruangan atau jumlah frekuensi kekerasan dalam acara televise dapat disebut sebagai variabel aktif, sedangkan kebalikannya yakni variabel yang tak dapat dikendalikan seperti tingkat kecerdasan, status social atau jenis kelamin disebut variabel atribut.

3. Variabel kontinyu dan Variabel Diskret Variable kontinyu adalah variable yang secara teoritis dapat mempunyai nilai yang bergerak tak terbatas antara dua nilai, sedangkan variable yang hanya memiliki satu nilai tertentu saja dan tidak ada nilai pecahan.

Konsep yang menghasilkan konstruk dan berkembang menjadi variabel membentuk pemberian pengertian atas konsep yang telah ditemukan yang terbagi atas definisi formal yang dikenal dengan definisi kamus karena istilah atau sinonimnya dianggap sudah dipahami oleh pembaca, Serta definisi operasional berupa pernyataan bagaimana operasi atau kegiatan yang harus dilakukan untuk memperoleh data atau indikator yang menunjukan konsep yang dimaksud. Definisi 
ini bermaksud menghubungkan konsep atau konstruk yang diteliti dengan gejala empirik.

\section{METODOLOGI PENELITIAN}

\subsection{Umum}

Metode yang digunakan pada penelitian ini adalah metode analisis deskriptif kuantitatif. Deskriptif kuantitatif berarti pemaparan masalah yang ada pada faktor keterlambatan proyek disertai dengan perhitungan waktu, sedangkan analisis berarti menggunakan fakta atau informasi yang telah tersedia kemudian informasi tersebut disusun, dijelaskan, kemudian dianalisis. Metode ini melakukan analisis status sekelompok manusia, suatu obyek, suatu set kondisi, suatu system pemikiran, ataupun suatu kelas peristiwa pada masa sekarang. Tujuan dari penelitian deskriptif ini adalah untuk membuat deskipsi, gambaran atau lukisan secara sistematis, faktual dan akurat mengenai fakta-fakta, sifat-sifat serta hubungan antar fenomena yang diselidiki pada studi kasus Pembangunan Rawat Inap Puskesmas Sungai Guntung Kecamatan Kateman Kab. Inhil, sehingga diperoleh hubungan antara variabel yang dianalisis, yaitu hubungan antara faktor keterlambatan dan scedul waktu pelaksanaan.

Berdasarkan gambar 1 bagan alir (flowchart) merupakan alur metode penelitian yang akan peneliti tuliskan. Berikut adalah bagan alir (flowchart).

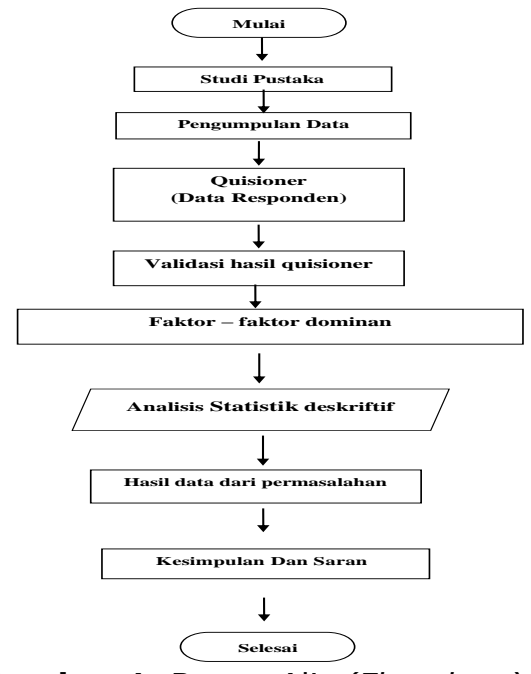

Gambar 1 Bagan Alir (Flowchart) Sumber. Data olahan

\section{ANALISIS DAN PEMBAHASAN}

\subsection{Pendahuluan}

Pelaksanaan penelitian ini dilakukan sesuai dengan metodologi penelitian yang telah dijelaskan pada Bab 3. Pada bab ini penulis akan menjelaskan tahapan penelitian dimulai dari pengumpulan data hingga analis yang digunakan untuk mengolah data dengan bantuan program statistik. Pengumpulan data penelitian dilakukan secara tiga tahap melalui penyebaran kuesioner yang variabelnya telah ditentukan. Tahap pertama adalah validasi variabel penelitian pakar di bidang konstruksi. Setelah didapat variabel yang telah disetujui oleh pakar, dilakukan pengumpulan data tahap kedua yaitu penyebaran kuesioner kepada pelaksana konstruksi untuk mendapatkan besar dampak dari variabel. Data yang didapat pada tahap dua akan dianalisis menggunakan perhitungan statistik dan bantuan program SPSS sehingga didapatkan peringkat dampak terbesar terhadap keterlambatan dan rendahnya kualitas hasil pekerjaan. Pengumpulan data tahap tiga adalah validasi akhir variabel yang didapat dari hasil analisis kepada pakar untuk mendapatkan masukan/komentar mengenai dampak variabel tersebut terhadap keterlambatan proyek. Lebih lengkapnya akan dijelaskan pada subbab berikut.

\subsection{Pengumpulan Data Tahap Pertama}

Penyebaran kuesioner tahap pertama ini merupakan tahapan menvalidasi variabelvariabel yang terdapat dalam kuesioner oleh pakar di bidang konstruksi dalam bidang akademik maupun praktisi yang memiliki pengalaman dan pengetahuan luas.Pakar memberikan komentar setuju atau tidak setuju dan tanggapan terhadap variabel penelitian. Output yang didapatkan dari validasi terhadap pakar berupa perubahan kalimat penulisan, penambahan variabel dan pengurangan variabel yang dianggap tidak relevan dengan tujuan penelitian, dan kuesioner akhir hasil olahan dikembalikan lagi ke pakar untuk ditanggapi.

Responden yang dipilih pada tahap ini adalah sebanyak 3 orang responden yang terdiri Owner, kontraktor dan konsultan yang berpengalaman di bidang konstruksi lebih dari 20 tahun.

\subsection{Pengumpulan Data Tahap Kedua}

Pengumpulan data tahap kedua ini merupakan penyebaran kuesioner kepada responden yang terkait dalam proyek pembangunan rawat inap puskesmas guntung dan responden umum yang berpengalaman minimal 3 tahun dalam bidang proyek konstruksi di Kabupaten Indragiri Hilir.

Kuesioner disebarkan sebanyak 25 buah kepada responden. Kuesioner yang berhasil dikembalikan adalah sebanyak 20 
buah atau dengan kata lain tingkat pengembalian sebanyak $80 \%$, .

\subsection{Uji Validitas dan Reliabilitas}

Sebelum memulai pengolahan data secara keseluruhan ada baiknya kita menguji terlebih dahulu Reliability (keterpercayaan, keterandalan, konsistensi) atau tidaknya suatu data yang di peroleh dengan kuestioner. Ada dua syarat bila suatu instrumen (Kuestioner) dikatakan baik, yaitu Valid dan Reliabel. Suatu instrumen dikatakan valid bila butir-butir pertanyaan atau pernyataan pada instrumen tersebut mampu mengungkapkan sesuatu yang akan diukur oleh instrumen tersebut.

Tujuan utama pengujian Realibilitas adalah untuk mengetahui konsestensi atau keteraturan hasil pengukuran apabila instrument tersebut di gunakan lagi sebagai alat suatu alat ukur responden. Hasil uji reabilitas mencerminkan dapat dipercaya atau tidaknya suatu instrument penelitian berdasarkan tingkat kemantapan dan ketepatan alat ukur dalam pengertian bahwa hasil pengukuran yang di dapatkan merupakan ukuran yang benar dari suatu ukuran.

Alpha Cronbach diukur berdasarkan skala alpha Cronbach 0 sampai 1. Jika skala itu dikelompok ke dalam lima kelas dengan range yang sama, maka ukuran kemantapan Alpha dapat di interprestasikan sebagai berikut:

\subsubsection{Uji Validitas}

Uji validitas menggunakan SPSS dengan metode corrected-item- correlation dan membandingkan nilai $r$ yang didapatkan dengan nilai tabel $r$. Setelah melakukan beberapa analisis, didapatkan hasil seperti berikut.

Tabel 1. Hasil Uji Corrected-Item-Correlation

\begin{tabular}{|l|l|l|l|l|l|}
\hline & $\begin{array}{l}\text { Scale } \\
\text { Mean if } \\
\text { Item } \\
\text { Deleted }\end{array}$ & $\begin{array}{l}\text { Scale } \\
\text { Variance } \\
\text { if Item } \\
\text { Deleted }\end{array}$ & $\begin{array}{l}\text { Correcte } \\
\text { d Item- } \\
\text { Total } \\
\text { Correlati } \\
\text { on }\end{array}$ & $\begin{array}{l}\text { Cronbac } \\
\text { h's } \\
\text { Alpha if } \\
\text { Item } \\
\text { Deleted }\end{array}$ & $\begin{array}{l}\text { Valid } \\
\text { asi }\end{array}$ \\
\hline X1 & 40.30 & 31.168 & .834 & .879 & Ya \\
X5 & 39.45 & 38.366 & .464 & .901 & Ya \\
X6 & 40.15 & 36.345 & .520 & .898 & Ya \\
X10 & 39.95 & 34.997 & .491 & .901 & Ya \\
X13 & 40.60 & 31.832 & .792 & .882 & Ya \\
X14 & 40.00 & 33.263 & .820 & .882 & Ya \\
X16 & 40.25 & 32.829 & .738 & .885 & Ya \\
X17 & 40.35 & 33.503 & .624 & .893 & Ya \\
X23 & 40.90 & 35.884 & .478 & .900 & Ya \\
\hline X33 & 40.05 & 34.787 & .539 & .897 & Ya \\
X36 & 40.00 & 34.526 & .747 & .887 & Ya \\
\hline
\end{tabular}

Sumber, Hasil Olahan

\subsubsection{Uji Reliabilitas}

Uji reliabilitas menggunakan SPSS dengan metode Cronbach's Alpa membandingkan nilai $r$ yang didapatkan dengan nilai tabel $r$. Setelah melakukan beberapa analisis, didapatkan hasil seperti berikut

Tabel 2. Hasil Uji Cronbach's Alpa

\begin{tabular}{|l|l|}
\hline Cronbach's Alpha & N of Items \\
\hline .900 & 11 \\
\hline \multicolumn{2}{|c|}{ Nilai r dicari menggunakan tabel $r$ uji } \\
\hline
\end{tabular}
dua sisi dengan level signifikan 0.05. Untuk jumlah data ( $n$ ) sebanyak 20, diperoleh nilai $r$ sebesar 0.443. Nilai $r$ ini kemudian dibandingkan dengan nilai cronbach's alpha output. Jika nilai cronbach's alpha lebih besar dari nilai r, maka kuesioner dikatakan reliabel. Didapatkan nilai cronbach's alpha lebih besar dari nilai $r$, sehingga kuesioner dinyatakan reliabel.

\subsection{Faktor - factor dominan}

1. Pengujian $\mathrm{K}$ sampel bebas dengan Uji Kruskal-Wallis untuk kategori Pengalaman Kerja

Pengalaman kerja responden yang ada dikategorikan menjadi 5 kelompok

a. Pengalaman kerja $<6$ tahun

b. Pengalaman kerja 6-10 tahun

c. Pengalaman kerja 11-15 tahun

d. Pengalaman kerja 16-20 tahun

e. Pengalaman kerja $>20$ tahun

Data dianalisa menggunakan bantuan prgram SPSS dengan pengujian $k$ independent samples. Hipotesis yang diajukan.

Ho = Tidak ada perbedaan persepsi pada responden yang berbeda pengalaman kerja

$\mathrm{Ha}=\mathrm{Ada}$ perbedaan persepsi pada responden yang berbeda pengalaman kerja

Dengan menggunakan level signifikansi (a) sebesar 0.05. Pedoman yang digunakan untuk menerima atau menolak hipotesis nol (Ho) kuesioner diusulkan :

a. Ho diterima jika nilai $p$-value pada kolom Asymp. Sig(2 Tailed) > level signifikansi (a) sebesar 0.05 dan nilai chi square < dari nilai x2 0.05 (df)

b. Ho ditolak jika nilai p-value pada kolom Asymp. Sig(2 Tailed) < level signifikansi (a) sebesar 0.05 dan nilai chi square > dari nilai x2 0.05 (df)

Setelah dilakukan beberapa analisis, didapatkan output hasil nilai sebagai berikut: 
Tabel 3. Hasil uji pengaruh pengalaman kerja terhadap presepsi responden

\begin{tabular}{|c|c|c|c|c|c|c|}
\hline & $\mathrm{X} 1$ & X5 & X6 & X10 & X13 & X14 \\
\hline \multirow{4}{*}{$\begin{array}{l}\text { Chi- } \\
\text { Square } \\
\text { df } \\
\text { Asymp. } \\
\text { Sig. } \\
\end{array}$} & 2.944 & 2.473 & 6.504 & 5.589 & 1.810 & 2.790 \\
\hline & 4 & 4 & 4 & 4 & 4 & 4 \\
\hline & .567 & .649 & .165 & 232 & .771 & .594 \\
\hline & X16 & X17 & X23 & X33 & X36 & \\
\hline $\begin{array}{l}\text { Chi- } \\
\text { Square }\end{array}$ & 5.283 & 4.343 & 1.959 & 3.617 & .942 & \\
\hline & 4 & 4 & 4 & 4 & 4 & \\
\hline $\begin{array}{l}\text { Asymp. } \\
\text { Sig. }\end{array}$ & .259 & .362 & .743 & .460 & .918 & \\
\hline
\end{tabular}

Sumber, Hasil Olahan

Hasil olahan menunjukkan bahwa semua nilai $p$-value pada kolom Asymp. Sig(2 Tailed) lebih besar dari level signifikansi (a) sebesar 0.05. Maka Ho diterima. yaitu terdapat tidak terdapat perbedaan presepsi pada responden yang memiliki perbedaan pengalaman kerja.

1. Pengujian $\mathrm{K}$ Sampel Bebas dengan Uji Kruskal-Wallis untuk Kategori pendidikan

Pendidikan responden yang ada dikategorikan menjadi 3 kelompok yaitu:

a. STM/SMK

b. $S 1$

c. $\mathrm{S} 2$

Data dianalisa menggunakan bantuan prgram SPSS dengan pengujian $k$ independent samples. Hipotesis yang diajukan.

$\mathrm{Ho}=$ Tidak ada perbedaan persepsi pada responden yang berbeda pengalaman kerja

$\mathrm{Ha}$ = Ada perbedaan persepsi pada responden yang berbeda pengalaman kerja

Dengan menggunakan level signifikansi

(a) sebesar 0.05. Pedoman yang digunakan untuk menerima atau menolak hipotesis nol (Ho) kuesioner diusulkan :

a. Ho diterima jika nilai $p$-value pada kolom Asymp. Sig(2 Tailed) > level signifikansi (a) sebesar 0.05 dan nilai chi square < dari nilai $\mathrm{x}^{2} 0.05(d f)$

b. Ho ditolak jika nilai p-value pada kolom Asymp. Sig(2 Tailed) < level signifikansi (a) sebesar 0.05 dan nilai chi square $>$ dari nilai $\times 20.05$ (df)

Setelah dilakukan beberapa analisis, didapatkan output hasil nilai sebagai berikut
Tabel 4 Hasil Uji Pengaruh Pendidikan Terhadap Presepsi Responden

\begin{tabular}{|c|c|c|c|c|c|c|}
\hline & X1 & $\times 5$ & X6 & X10 & X13 & X14 \\
\hline \multirow{4}{*}{$\begin{array}{l}\text { Chi- } \\
\text { Square } \\
\text { df } \\
\text { Asymp. } \\
\text { Sig. }\end{array}$} & .451 & 2.436 & 1.590 & . 118 & 3.379 & 2.983 \\
\hline & 2 & 2 & 2 & 2 & 2 & 2 \\
\hline & & & & .943 & & \\
\hline & X16 & X17 & $\times 23$ & X33 & X36 & \\
\hline $\begin{array}{l}\text { Chi- } \\
\text { Square }\end{array}$ & .991 & .043 & 3.241 & .190 & 2.292 & \\
\hline df & 2 & 2 & 2 & 2 & 2 & \\
\hline $\begin{array}{l}\text { Asymp. } \\
\text { Sig. }\end{array}$ & .609 & .979 & .198 & .909 & .318 & \\
\hline
\end{tabular}

Sumber:hasil olahan

\subsection{Analisis Statistik Deskriptif}

Analisis ini menunjukan gambaran sekilas dan ringkas mengenai data yang didapat. Analisis statisik dekriptif dilakukan dengan menggunakan program SPSS, sehingga didapat nilai rata-rata (mean) dan standar deviasi.

Sebagain besar variabel keterlambatan memiliki nilai mean diatas 3. Dari 11 variabel $x$ yang diperoleh dari analisi statisik dekriptif dilakukan dengan menggunakan program SPSS rangking 1 hanya 1 variabel, yaitu $\times 5$ dari aspek sumber daya manusia dengan factor Kurangnya tenaga kerja terampil.

\section{KESIMPULAN}

Penelitian pada studi kasus Pembangunan Rawat Inap Puskesmas Sungai Guntung Kecamatan Kateman Kab. Inhil Tahun Anggaran 2017, maka berdasarkan pembahasan penelitian yang didapatkan dari hasil pendapat 20 responden yang dilakukan menggunakan pertanyaan kuisioner yang akhir kesimpulan adalah sebagai berikut,

1. Faktor-faktor utama yang berpengaruh terhadap keterlambatan proyek peringkat 1 yang paling dominan adalah Kurangnya tenaga kerja terampil masuk dalam kategori aspek sumber daya manusia.

2. Faktor berikutnya yang berpengaruh terhadap keterlambatan proyek peringkat 2 yang dominan adalah keadaan cuaca yang tak terduga masuk dalam kategori aspek eksternal

3. Faktor berikutnya yang berpengaruh terhadap keterlambatan proyek peringkat 3 yang dominan adalah perbedaan intepretasi kode pekerjaan masuk dalam 
kategori aspek organisasi, koordinasi dan komunikasi.

Berdasarkan data dilapangan yang peneliti dapatkan yang bersumber dari kontrak pelaksanaa proyek Pembangunan Rawat Inap Puskesmas Sungai Guntung Kecamatan Kateman Kab. Inhil Tahun Anggaran 2017 adalah waktu pelaksanaan pekerjaan yang singkat waktu yang dimulai tanggal kontrak 31 Agustus 2017 hingga 12 Desember 2017 dengan waktu pelaksaan 104 hari kerja. Kemudian penambahan waktu pelaksanaan 50 hari kerja dimulai perjanjian kerja tanggal 27 desember hingga tanggal 03 Februari 2018 harus menyelesaikan pekerjaan.

Waktu pelaksanaan pada kontrak yang sangat singkat 104 hari kerja adalah tidak efektif untuk menyelsaikan pekerjaan konstruksi. Pelaksanaan pekerjaan konstruksi yang maksimal seharusnya adalah 180 hari kerja untuk endapatkan efesiansi waktu yang cukup.

\section{Daftar Pustaka}

[1] A Guide, 2008. Project Management Body Of Knowledge

[2] Amien sajekti. 2011 Metode Kerja Bangunan Sipil. Jakarta

[3] Sugiyono. (2013). Metode Penelitian Bisnis, Bandung

[4] Ervianto, Wullfram. 2005. Manajemen Proyek Konstruksi. Andi. Yogyakarta

[5] Irika Widiasanti \& Lenggogeni. 2013 Manajemen Konstruksi. Bandung

[6] Kaming, P.F.,dkk; 2000. Analisa Keterlambatan Pelaksanaan Pekerjaan proyek

[7] Nicholas. M, John. 2008 Project Management For Business Engineering And Technology.

[8] Proyek- proyek Konstruksi, Yogyakarta

[9] Rakhmat, Jalaluddin.1997. Metode penelitian Komunikasi, dilengkapi contoh analisis statistic. Bandung: PT Remaja Rosdakarya

[10] Soehartono, Irawan. 1999. Metode Penelitian social: suatu teknik penelitian bidang kesejahteraan sosial dan ilmu sosial lainnya. Bandung: PT Remaja Rosdakarya 